\title{
Environmental and technological carrot safety conditions Part II. Changes in nitrites contents determined by the environment and processing
}

\section{Środowiskowe i technologiczne uwarunkowania jakości marchwi. Część II. Zmiany zawartości azotynów determinowane jakością środowiska i procesami przetwarzania}

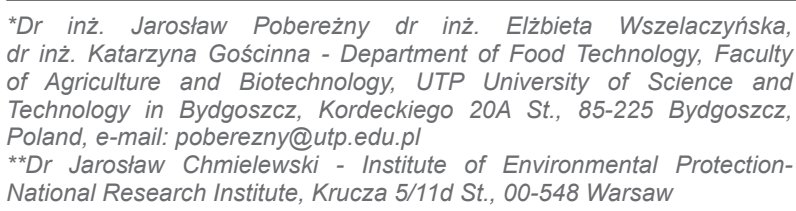

Keywords: environment, nitrites, Mg, carrot, processing, daily intake

Słowa kluczowe: środowisko, azotyny, Mg, marchew, przetwarzanie, dzienne spożycie

\begin{abstract}
The aim of the present research was to determine the effect of environmental conditions (biofortification with $\mathrm{Mg}$ ) and technological processes (freezing, preserving in jars and drying) on the content of nitrates (III) in carrot. Besides this, the amount of human intake of nitrates (III) found in the carrot products analysed was assayed. The effect on environment resulting from the changes in carrot growing technology was not so unambiguous as for nitrates (V) since most $\mathrm{NO}_{2}^{-}$was contained in, for example, processed foods from non-biofortified Mg material. The consumption of products was not hazardous to the consumer since it did not exceed Acceptable Daily Intake (ADI) $\mathrm{NO}_{2}^{-}$. Most nitrates (III) are consumed with dried carrot and least - with carrot preserved in jars. For this reason, one should run a thorough monitoring of the contents of nitrates (III), toxic to humans since new products based on dried carrot material, such as crisps, are launched in the consumer market.
\end{abstract}

๑) IOŚ-PIB

\section{INTRODUCTION}

Nitrites $\left(\mathrm{NO}_{2}^{-}\right)$are considered to be poisonous since in human bodies, they impair the supply of oxygen by blood; methaemoglobin [Błaszczuk et al. 2008, Bottex et al. 2008, Gajewska et al. 2009 , Łozowicka 2009]. It is especially hazardous to new-born children, small children and the diseased as well as to the elderly. Nitrites also react with secondary and tertiary amines forming nitrosamines, proven carcinogenic and mutagenic. They also show a destructive effect on vitamins group $A$ and $B$ as well as carotenoids [Murawa et al. 2008, Marks 2009]. Nitrates (III) are also formed as a result of reduction of nitrates $(\mathrm{V})$. The process can intensify still before vegetable consumption, for example, during a longer transport and storage at temperature lower than

\section{Streszczenie}

Celem przeprowadzonych badań było określenie wpływu warunków środowiska (biofortyfikacja Mg) i procesów technologicznych (mrożenie, konserwowanie w słoikach i suszenie) na zawartość azotanów(III) w marchwi. Ponadto określono wielkość spożycia przez człowieka azotanów(III) znajdujących się w badanych przetworach z marchwi. Wpływ środowiska wynikający z wprowadzonych zmian w technologii kultywacji marchwi nie był tak jednoznaczny jak dla azotanów(V), gdyż najwięcej $\mathrm{NO}_{2}^{-}$zawierały $\mathrm{m}$. in. przetwory uzyskane z surowca niebiofortyfikowanego Mg. Spożycie badanych przetworów nie było niebezpieczne dla konsumenta, gdyż nie przekraczano dopuszczalnej normy dziennego spożycia (ADI) $\mathrm{NO}_{2}^{-}$. Najwięcej azotanów(III) spożywamy z marchwią suszoną a najmniej z marchwią konserwowaną w słoikach. $Z$ tego względu należy prowadzić szczegółowy monitoring zawartości trujących dla człowieka azotanów(III), gdyż na rynek konsumencki wprowadza się nowe produkty oparte o susz z marchwi między innymi chipsy.

recommended [Amr, Hadidi 2001; Ziarati, Arbabi-Bidgoli 2014]. To evaluate the amount of toxic nitrates (III) intake by human body with the ration consumed, investigating the nitrates content exclusively in fresh vegetables is insufficient. It turns out that vegetable peeling, washing and processing decrease the content of the hazardous compounds [Zalewski, Gołaszewska 2001, Grudzińska, Zgórska 2005].

The aim of the present research has been to define the changes in the content of $\mathrm{NO}_{2}^{-}$determined by the environment and processing in the products made from carrot of five cultivars, orange in colour. Additionally, the amount of human consumption of toxic compounds found in processed foods was assayed. 


\section{MATERIALS AND RESEARCH METHODS}

Detailed methodology is given in part I.

In material and once it has been preserved in products, the content of ions $\mathrm{NO}_{2}^{-}$was assayed once they were oxidized to $\mathrm{NO}_{3}{ }^{-}$, in an earlier prepared extract sample using multifunctional computer device CX-721 provided by Elmetron [Baker, Thompson 1992].

The paper is an attempt at model-oriented determination of the total daily intake of nitrates (III) assuming the consumption of 55 $\mathrm{g}$ of processed carrot foods per person. The data was compared with norms considering the Acceptable Daily Intake (ADI). The results have been presented as arithmetic means.

The results of 3-year research were exposed to statistical calculations. The analysis of statistical differences was performed with the analysis of variance ANOVA supported with post-hoc Tukey test at the significance level of $\alpha=0.05$ with STATISTICA 12.0 software.

\section{RESULTS AND DISCUSSION}

The results of the content of nitrates (III) in frozen foods from five cultivars are given in Figure 1. The analysis of variance showed significant differences in the content of nitrates (III) between frozen foods from the five cultivars. Additionally, there were significant differences seen in the content of nitrates (III) between frozen foods from carrot biofortified with magnesium, as compared with frozen foods from carrot without biofortification. The lowest content of nitrates (III) was reported for frozen foods from 'Perfekcja', 'Berjo' and non-biofortified carrot. However, the highest content was recorded for frozen foods derived from 'Flacoro' and from magnesium-biofortified carrot at the amount of $90 \mathrm{~kg}$ (worsening environmental conditions). The same relationships were received for carrot preserved in jars and dried carrot (Figure 2). Interestingly, each magnesium amount applied increased the content of nitrates (III) in processed foods, as compared with the products from nonbiofortified carrot. This is related to the assimilation of nitrogen by higher plants by lowering the $\mathrm{pH}$ of the soil due to the use of $\mathrm{Mg}$ that displaces $\mathrm{Ca}$ from the soil complex.
According to Wszelaczyńska et al. [2014], biofortification of carrot with magnesium increases the content of nitrates (III) in material. A higher content of nitrates (III) in processed foods, as compared with processed foods from non-fertilised carrot, can be related to an increase in the content of nitrates (III) in carrot roots due to carrot biofortification with magnesium in a sulphate form. This is due to the environment conditions. As reported by Smoleń et al. [2006], plant biofortification with magnesium in a sulphate form results in an increase in the concentration of sulphate anions in carrot roots, an excess of which can result in the accumulation of nitrates (III). Contents of nitrates (III) in carrot reported by other authors are much lower and amount to 1.01 [Ziarati, ArbabiBidgoli 2014], 0.65 [Ayaz et al. 2007], 0.57 [Murawa et al. 2008] as well as $0.5 \mathrm{mg} \mathrm{kg}-1$ of fresh weight noted by Sus et al. [2006]. Interestingly, the values recorded by other authors refer to fresh carrot and not, as in the present research, processed foods; for that reason, one can claim that the products contained high amounts of nitrates (III), especially, as reported by other authors, processing always resulted in a decrease in the content of nitrates [Wachowicz, Czarniecka-Skubina 2004 and Grudzińska, Zgórska 2005, Rytel et al. 2013, Zalewska - Korona et al. 2015].

The results of the present research of changes in the content of nitrates (III) due to processing are provided in Figures 1 and 2. Each processing technology applied decreased the content of nitrates (III). Loss of nitrates (III) in preservation process was highest and it was on average for cultivars - $35 \%$, for dried carrot - the loss accounted for an average of $18 \%$ and the lowest - for freezing process $-16 \%$. Such result is confirmed by the reports by Wachowicz, Czarniecka-Skubina [2004], Grudzińska, Zgórska [2005], Rytel et al. [2013], Zalewska - Korona et al. [2015]. Wachowicz, Czarniecka-Skubina [2004], Grudzińska, Zgórska [2005] and Rytel et al. [2013] noted a high solubility of nitrates in water, which can result in a considerable loss of those harmful compounds throughout the preservation process.

According to Rytel et al. [2013], already the process of blanching itself decreases the content of nitrates (III) by about $20 \%$. As reported by Zalewska - Korona et al. [2015], the content of nutrients in frozen products differs slightly only from the raw material; hence, a lower loss due to that process and

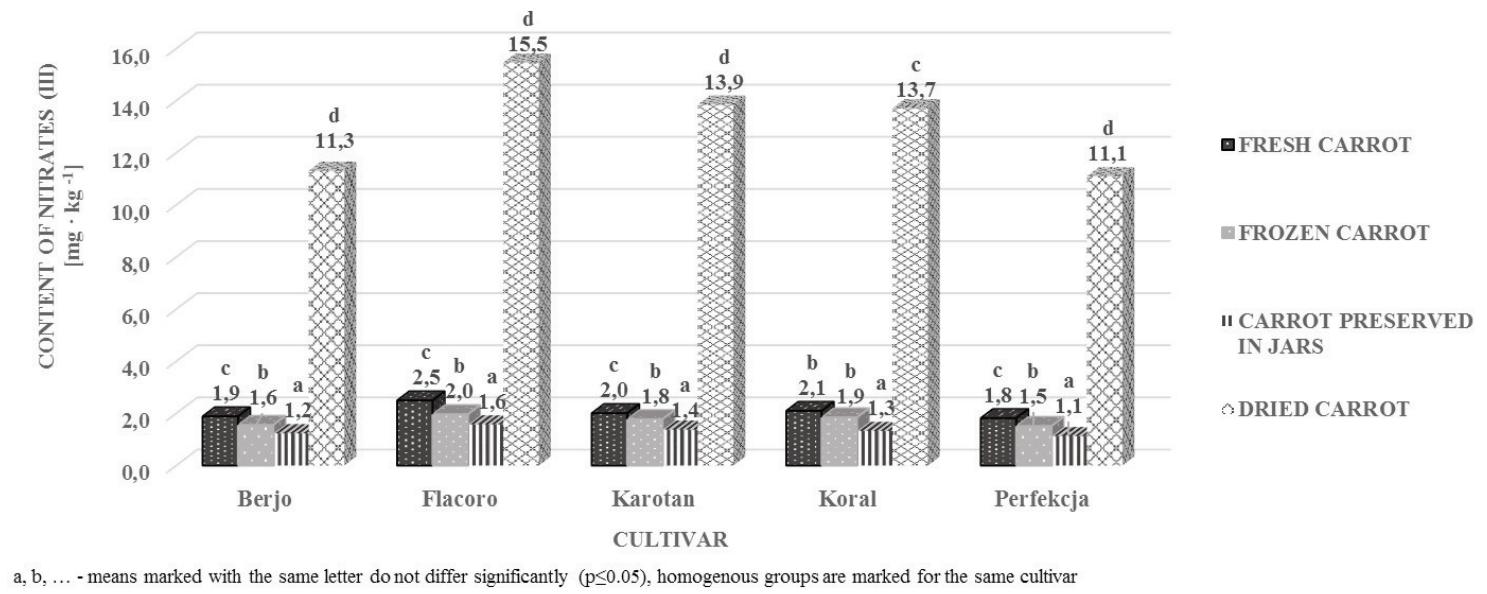

Figure 1. Content of nitrites (III) in processed carrot foods depending on genetic conditions. 


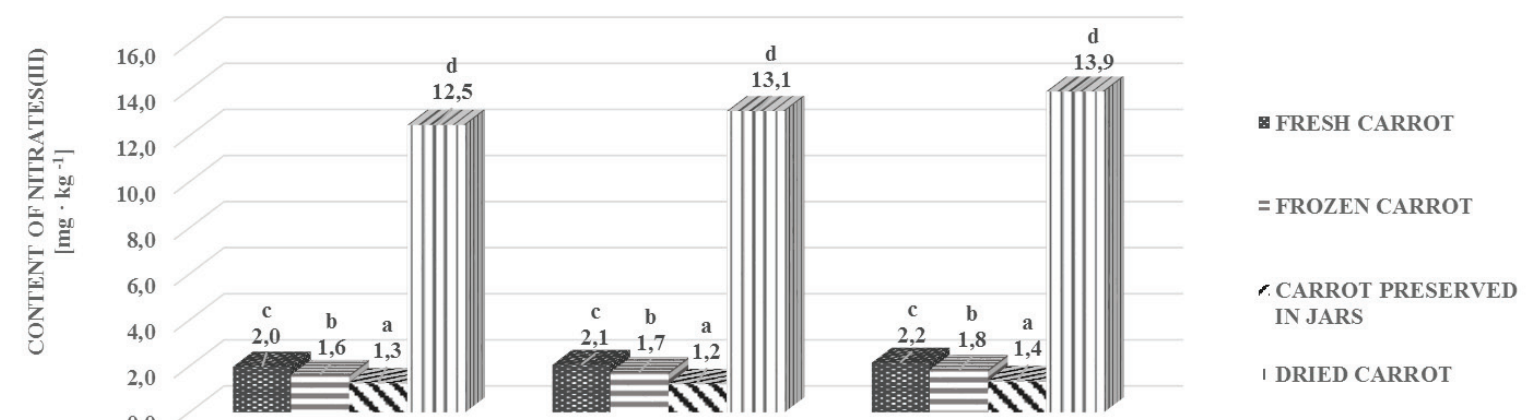

0

45

90

MAGNESIUM RATE $\left[\mathrm{kg} \mathrm{MgO} \cdot \mathrm{ha}^{-1}\right]$

$a, b, \ldots$ - means marked with the same letter do not differ significantly $(\mathrm{p} \leq 0.05)$, homogenous groups are marked for the same cultivar

Figure 2. Content of nitrites (III) in processed carrot foods depending on biofortification with magnesium.

Table 1. Daily intake of nitrates (III) for consumption of $55 \mathrm{~g}$ of carrot $^{\star}\left(\mathrm{mg} \cdot \mathrm{day}^{-1}\right)$.

\begin{tabular}{|c|c|c|c|c|}
\hline CULTIVAR & $\begin{array}{c}\text { Fresh carrot } \\
\text { (Directly after harvest) }\end{array}$ & Frozen carrot & Carrot preserved in jars & Dried carrot \\
\hline BERJO & 0.10 & 0.09 & 0.07 & 0.62 \\
\hline FLACORO & 0.14 & 0.11 & 0.09 & 0.85 \\
\hline KAROTAN & 0.11 & 0.10 & 0.08 & 0.76 \\
\hline KORAL & 0.12 & 0.10 & 0.07 & 0.75 \\
\hline PERFEKCJA & 0.10 & 0.08 & 0.06 & 0.61 \\
\hline \multicolumn{5}{|c|}{ MAGNESIUM APPLICATION ** } \\
\hline 0 & 0.11 & 0.09 & 0.07 & 0.69 \\
\hline 45 & 0.11 & 0.10 & 0.07 & 0.72 \\
\hline 90 & 0.12 & 0.10 & 0.07 & 0.76 \\
\hline MEAN & 0.11 & 0.10 & 0.07 & 0.72 \\
\hline
\end{tabular}

ADI - Acceptable Daily Intake ${ }^{* * *}$ for nitrates(III) is $4.2 \mathrm{mg} \cdot$ day $^{-1}$ for adult's weight of $-60 \mathrm{~kg}$.

* - mean consumption of fresh and processed carrot (without juice) is $20 \mathrm{~kg} \cdot y e a r^{-1}$ per person in Poland.

** - Magnesium rate $\left[\mathrm{kg} \mathrm{MgO} \cdot \mathrm{ha}^{-1}\right]$

*** - The Joint FAO/WHO Expert Committee [JECFA 2002] for foodstuffs has determined the (ADI) daily intake of nitrates (III) by adult amounting to $0-0.07 \mathrm{mg}$ per $\mathrm{kg}$ of body weight [Burt et al. 1993].

Rytel et al. [2013] claim that thermal processing with high temperatures and drying, does not show a high effect on the loss of nitrates in material. Dried carrot material is added to foods to be processed further and they are a semi-finished product. With that in mind, due to growing consumer requirements in terms of food quality and safety, monitoring the content of antifeedant compounds in storage roots in carrot and in its products has become necessary.

According to various sources, vegetable consumption, including carrot, should be about $500 \mathrm{~g}$ in 4-5 meals per day. An attempt was made at a model-determination of daily nitrates (III) intake (Table 1). Irrespective of the factors of the experiment, consuming $55 \mathrm{~g}$ of carrot, we consume nitrates (III); maximum of $0.72 \mathrm{mg}$ and minimum $0 \mathrm{f}$.07, which accounts for $17.1 \%$ and
1.7\% ADI (Acceptable Daily Intake), respectively. Most nitrates (III) are consumed with dried carrot and least - with preserved carrot. Such information is of much importance for today's processing market, since recently, carrot crisps have been launched for sale. However, consuming the products under study was not hazardous for the consumer since it did not exceed the Acceptable Daily Intake of nitrates. Zhong et al. [2002], monitoring the Chinese market and Petersen, Soltze [1999] - the Danish market, determined the daily intake of nitrates (III) of $0.68 \mathrm{mg}$ day $^{-1}$ and from 0.09 to $0.50 \mathrm{mg} \mathrm{day}^{-1}$, respectively. Similarly, as in the present research, the norm was not exceeded. However, Tamme et al. [2006], investigating the Estonian market, did not find any nitrates (III) in vegetables. 


\section{CONCLUSIONS}

Changes triggered by the application of biofortification of plants with magnesium enhanced the environmental conditions for carrot cultivation over the vegetation period, which decreased the content of nitrates (III), especially in frozen carrot. At that time applying magnesium at the rate of $90 \mathrm{~kg} \mathrm{MgO}$ was most beneficial. The content of nitrates (III) in processed foods significantly depended on the genetic conditions of material and on the processing method. The processing technology and genetic

\section{REFERENCES}

AMR A., HADIDI N. 2001. Effect of cultivar and harvest date on nitrate (NO3) and nitrite (NO2) content of selected vegetable grown under open field and greenhouse conditions in Jordan. Journal of Food Composition and Analysis 14: 59-67.

AYAZ A., TOPCU A., YURTTAGUL M. 2007. Survey of nitrate and nitrite levels of fresh vegetables in Turkey. Journal of Food Technology 5: 177-179.

BAKER W. H., THOMPSON T. L. 1992. Determination of nitrate nitrogen in plant samples by selective ion electrode. Plant Analysis Reference Procedures the Southern Region of the United States (SCSB \# 368): 23-26.

BŁASZCZUK B., MURAWAD., BANASZKIEWICZ T., MAJEWSKA E., SULIMA J. 2008. Zawartość azotanów(III) i (V) w wybranych gatunkach warzyw i ziemniakach dostępnych w handlu w Olsztynie w latach 2003-2004. Bromatologia 41: 67-71.

BOTTEX B., LOU J., DORNE C.M., CARLANDER D, BEDFORD D., PRZYREMBEL H., HEPPNER C., KLEINER J., COCKBURN A. 2008. Risk - benefit health assessment of food Food fortification and nitrate in vegetables. Trends Food Science and Technology 19: 109-115.

BURT T.P., HEATHWAITE A.L., TRUDGILL S.T. 1993. Nitrate: Process, pattern and management. Chichester, England, Wiley, 10-28.

GAJEWSKA M., CZAJKOWSKA A., BARTODZIEJSKA B. 2009. The content of nitrates(III) and (V) in selected vegetables on detail sale in Lodz region. Ochrona Środowiska i Zasobów Naturalnych 40: 388-395.

GRUDZIŃSKA M., ZGÓRSKA K. 2005. Effect of preliminary and thermal processing on the content of nitrate in vegetables. Rocznik Ochrony Środowiska 7: 233-241

JECFA. 2002. Commission Regulation No. 563/2002 of 2 April 2002 amending Regulation (EC) No 466/2001 setting maximum levels for certain contaminants in foodstuffs. FAO/WHO Expert Committee on Food Additives (JECFA). Official Journal of the European Communities L86, 03/04/2002: 5-6.

ŁOZOWICKA B. 2009. Chemiczne zanieczyszczenia żywności pochodzenia roślinnego. Progres in Plant Protection 49: 20712080.

MARKS N. 2009. Zawartość azotanów, azotynów i metali ciężkich w bulwach ziemniaka w zależności od długości okresu przechowywania. Inżynieria Rolnicza 1: 183-187.

MURAWAD., BANASZKIEWICZB., MAJEWSKAE., BŁASZCZUK B., SULIMA J. 2008. Zawartość azotanów (III) i (V) w wybranych conditions affected the safety of products and consequently, the safety of consumers.

Of all the cultivars studied, 'Karotan' was least applicable to processing since, irrespective of the processing method, for that cultivar the decrease in nitrates (III) was lowest. The calculated mean daily intake of carrot in a processed form does not exceed the ADI. Due to a toxic effect of nitrate compounds, regular monitoring of the content and occurrence of those compounds is necessary not only in material but also in processed foods to be sold in the market.

gatunkach warzyw i ziemniakach dostępnych w handlu w Olsztynie w latach 2003-2004. Bromatologia i Chemia Toksykologiczna 16: 67-71.

PETERSEN A., STOLTZE S. 1999. Nitrate and nitrite in vegetables on the Danish market: content and intake. Food Additives and Contaminants 16: 291-299.

RYTEL E., NEMŚ A., KUŁAKOWSKA K. 2013. Wpływ temperatury podsuszania na zawartość glikoalkaloidów i azotanów(V) podczas laboratoryjnej produkcji suszu z ziemniaków gotowanych. Żywność Nauka Technologia Jakość 1: 191-203.

SMOLEŃ S., WOJCIECHOWSKA R., SADY W., SZURAA., 2006. The effect of fertilization with different forms of nitrogen and foliar nutrition on yield and nitrogen metabolism

in carrot roots (Daucus carota L.). Acta Agrophysica 7: 721-732.

SUS J. KMECL V. GREGORCIC A. 2006. A survey of nitrate and nitrite content of fruit and vegetables grown in Slovenia during 1996-2002. Food Additives and Contaminants 23: 385-390.

TAMME T., REINIK M., ROASTO M., JUHKAM K., TENNO T., KIIS A. 2006. Nitrates and nitrites in vegetables and vegetablebased products and their intakes by the Estonian population. Food Additives and Contaminants 23: 355-361.

WACHOWICZ I., CZARNIECKA-SKUBINA E. 2004. Wpływ procesu kulinarnego na wybrane mierniki jakości marchwi i buraków. Żywność Nauka Technologia Jakość 3: 204-2017.

WSZELACZYŃSKA E., POBEREŻNY J., KEUTGEN A. 2014. Effect of Genetic Conditions, Foliar Fertilisation with Magnesium and Storage on the Content of Nitrates (V) and (III) in the Storage Roots in Carrot. Ochrona Środowiska i Zasobów Naturalnych 25: 7-11.

ZALEWSKI S., GOŁASZEWSKA B. 2001. Optimisation of potato quality in culinary process. Polish Journal of Food and Nutrition Sciences 1: 59-63.

ZALEWSKA-KORONA M., JABŁOŃSKA-RYŚ E., RADZKI W., GUSTAW W., SŁAWIŃSKA A., MICHALAK-MAJEWSKA M. 2015. Usefulness of selected broccoli varieties for freezing. Polish Journal of Food and Nutrition Sciences 30: 91-97.

ZIARATI P., ARBABI-BIDGOLI S. 2014. Investigation of cooking method on nitrate and nitrite content crops and vegetables and assess the associated health risk. International Journal of Plant, Animal and Environmental Sciences 4: 46-52.

ZHONG W., HU C., WANG M. 2002. Nitrate and nitrite in vegetables from north China: content and intake. Food Additives and Contaminants 19: 1125-1129. 